\title{
23. VEIN MINERALS IN BASALT, HOLE 462A, LEG 61 OF THE DEEP SEA DRILLING PROJECT1
}

\author{
Kenneth E. Windom and Patricia Book, Department of Earth Sciences, Iowa State University, Ames, Iowa
}

\begin{abstract}
Numerous veins are present in basalts recovered from Hole 462A, Leg 61 of the Deep Sea Drilling Project. Three mineral assemblages are recognized and stratigraphically controlled. These assemblages are (1) a zeolite-bearing, quartz-poor assemblage which occurs from Core 44 to the bottom of the hole and contains smectite, clinoptilolite, calcite, pyrite, \pm chabazite, \pm analcime, \pm quartz, \pm apophyllite, \pm talc (?); (2) a quartz-rich, pyrite-bearing assemblage, found between Cores 19 and 29, which contains smectite, calcite, quartz, and pyrite; and (3) a quartz-rich, celadonite-bearing assemblage which occurs from Cores 14 through 17 and contains smectite, calcite, quartz, celadonite, and Fe oxide.

These data are interpreted to represent two episodes of vein mineral formation with an oxidative overprint on the more recent. The first episode followed the outpourings of basaltic lavas onto the sea floor. Zeolite-bearing veins were formed at elevated temperatures under low $\mathrm{P}_{\mathrm{CO}_{2}}$, while the thermal gradient was high and before a cover of calcareous sediments had formed. The second mineralization episode followed injection of basalt and microdiabase sills into a thick layer of sediments, and produced all the vein minerals now occurring between Cores 14 and 29 . These veins formed at lower temperature and higher $P_{\mathrm{CO}_{2}}$ than the zeolite-bearing veins. The presence of pyrite indicates a nonoxidative environment. After the initial formation of these veins, oxygenated seawater diffused through the sedimentary cover and oxidized the pyrite and smectite, forming celadonite and $\mathrm{Fe}$ oxides.
\end{abstract}

\section{INTRODUCTION}

Hole 462A, drilled during DSDP Leg 61 , is situated in the Nauru Basin at $7^{\circ} 14.50^{\prime} \mathrm{N}, 165^{\circ} 1.90^{\prime} \mathrm{E}$. A total of 1068.5 meters of sediment and igneous rock was penetrated beneath 5187 meters of water. Igneous rock was encountered at 565 meters below bottom. Two igneous rock units are recognized: an upper unit $(155 \mathrm{~m}$ total thickness) of microdiabase and basalt sills, from a few centimeters to 50 meters thick, that have intruded a sequence of zeolitic volcaniclastic sediments, and a lower unit, of unknown total thickness, comprising thin and thick basaltic sheet flows or submarine pahoehoe units (Batiza et al., this volume).

Igneous rocks cored from Hole $462 \mathrm{~A}$ contain abundant secondary minerals which fill veins and occupy vesicles. We selected 48 samples of these secondary assemblages to determine the minerals present, search for a paragenetic sequence, and define any mineralogical variations present between the top and bottom of the hole. Such information is important because these secondary assemblages represent the only vestige of a once-pervasive fluid phase. Precise correlation between mineral assemblages and conditions of alteration is often ambiguous because of local inhomogeneities of either the host rock or the fluid phase and because of nucleation of metastable phases, but information about the nature of secondary assemblages can provide some understanding of the conditions prevailing during alteration.

Both optical and X-ray diffraction (XRD) techniques were used during this investigation. Mineralogy, tex-

\footnotetext{
${ }^{1}$ Initial Reports of the Deep Sea Drilling Project, Volume 61.
}

ture, and mineral relationships were determined from thin-section examination. Where confirmation of a mineral's identity was required, indices of refraction and/or XRD patterns $\left(\mathrm{CuK}_{\alpha}\right.$ radiation) were obtained.

\section{SECONDARY MINERALOGY}

Minerals occurring in veins from Hole $462 \mathrm{~A}$ include smectite, calcite, quartz, pyrite, celadonite, iron oxide (hydroxide?), clinoptilolite, chabazite, analcime, and talc (?). Apophyllite was also identified, but occurs only as a vesicle filling, never in veins. More detailed description of each mineral follows.

Smectite is ubiquitous throughout the section. It is very fine grained, and appears greenish brown to golden brown in thin section, except near the top of the section, where it is more reddish brown. It seems to have been the first mineral to have formed in the veins, because it invariably occurs as a rim along the vein walls. The texture of the smectite does not appear to vary much throughout the hole, but $\mathrm{X}$-ray diffraction data indicate that the smectite from the bottom (below Core 44) has a higher degree of crystallinity than that near the top.

Calcite occurs as both relatively coarse grained clearto-white subhedral to euhedral grains with excellent cleavage and as fine-grained aggregates of radiating crystals. There is no gradation between these two textures; where they occur together in the same vein, it appears that the fine-grained crystals formed later. Calcite is present throughout the section, but is more abundant above Core 44.

Quartz occurs predominantly in the upper part of the section (Cores 14-29), where it is a ubiquitous finegrained phase. Below Core 44 , it is less abundant and often identifiable only by X-ray diffraction analysis; it usually occurs here as finely disseminated crystals in the 
smectite or in small radiating patches. Quartz appears to be the most recently formed mineral in those samples where it occurs.

Celadonite occurs as a bright green platy fringe on the smectite and as platy aggregates and, less commonly, as fibers in calcite and quartz. In some instances, celadonite appears to have formed at the expense of smectite. Some samples contain celadonite both in the veins and in the groundmass of the host rock; it was never observed to occur in the groundmass without also occurring in veins, however. Celadonite is restricted to samples from Core 17 and above.

Pyrite is present as subhedral to euhedral crystals in Cores 19 through 29 , and is normally concentrated along the rims of the veins, in association with smectite. It occurs intermittently in Cores 44 through 90 and, when present, it is always present in, but not restricted to, the centers of the veins. In several samples it also occurs in small crystals associated with smectite near the vein wall.

Iron oxide (hydroxide?) occurs as reddish stains on smectite and calcite, and as a replacement product after pyrite. In Sample 462A-15-2, 41-48 cm (a), pseudomorphs of iron oxide after pyrite occur in the vein; pyrite and hematite are present together, in apparent reaction relation, in Sample 462A-19-1, 49-51 cm. Iron oxide is restricted to samples above Core 19 .

Clinoptilolite is common in the lower part of the hole. It is either clear or white, often with good cleavage. In glassy rocks, it appears to be the first secondary mineral formed, and in two samples it appears corroded. When corroded it always occurs with small amounts of analcime, which appears to be replacing the clinoptilolite. Clinoptilolite is present only as a vein mineral, never as a vesicle filling.

Analcime is present only in minor amounts, in two samples. It is clear to white and occurs in association with clinoptilolite in veins in the lower part of the hole.

Chabazite occurs as clear to white masses, often displaying twinning. It is restricted to vesicle fillings in the lower part of the hole.

Apophyllite is present only as white fibrous vesicle fillings in the lower part of the hole.

Talc(?) has been tentatively identified from X-ray patterns from four samples. Its identity has not been verified optically.

\section{Conditions of Secondary Mineral Formation}

Secondary minerals identified in these veins have been reported found before in altered deep-sea basalts. Smectite and celadonite have been recovered on Leg 17 (Bass et al., 1974), Leg 26 (Kempe, 1974), Leg 34 (Bass, 1976; Seyfried, Shanks, and Bischoff, 1976; Scott and Swanson, 1976; Kempe, 1976; Seyfried, Shanks, and Dibble (1978), Leg 35 (Kastner, 1976), Leg 37 (Andrews, 1977; Scarfe and Smith, 1977) and from dredge hauls from the Peru Trench (Scheidegger and Stakes, 1977; Scheidegger, 1979). The consensus appears to be that smectite forms early under relatively non-oxidizing conditions, incorporating $\mathrm{Fe}$ and $\mathrm{Mg}$ from altered olivine, pyroxenes, and glass. Celadonite appears to form later under relatively oxygen-rich conditions (Bass, 1976; Andrews, 1977; Seyfried, Shanks, and Dibble, 1978). Pyrite has been found in numerous deepsea basalts, but its origin is often ambiguous, even when isotopic data are available. For example, for Leg 34 rocks, Seyfried, Shanks, and Bischoff (1976) conclude that pyrite formed at low temperatures and cite $\delta^{34} \mathrm{~S}$ data that are consistent with low-temperature bacterial reduction of sea-water sulfate, whereas Scott and Swanson (1976) conclude that the pyrite-bearing veins formed at temperatures greater than $200^{\circ} \mathrm{C}$. They (Scott and Swanson) conclude that the isotopic data have too great a spread to distinguish among formation from bacterial reduction, inorganic reduction by reaction between sulfate and rock, and remobilization of magmatic sulfur.

Zeolites are common secondary minerals in both basalts and sediments (Iijima, 1978). Phillipsite is a common zeolite in deep-sea rocks, and has been shown to form during the alteration of volcanic glasses (Holler and Wirching, 1978). No phillipsite was detected in these rocks, however-only clinoptilolite, chabazite, and analcime. It has been suggested that phillipsite forms in a metastable manner in the marine environment and given enough time will react with silica to yield clinoptilolite, the thermodynamically more stable phase (Berger and von Rad, 1972; Stonecipher, 1976; Boles and Wise, 1978).

Clinoptilolite has been found in deep-sea sediments (Stonecipher, 1978; Boles and Wise, 1978; Hay, 1977, 1978; Kastner and Stonecipher, 1978), and in low-grade metamorphic rocks (Seki et al., 1969; Boles, 1977). Hawkins et al. (1978) succeeded in synthesizing clinoptilolite-both as a pure phase and in association with phillipsite and mordenite-at temperatures from $130^{\circ}$ to $150^{\circ} \mathrm{C}$ at $1 \mathrm{kbar}$, from volcanic ash in a $2 \mathrm{M}$ carbonate solution of $\mathrm{K}$ and $\mathrm{Na}$; but their work did not establish the upper or lower equilibrium thermal stabilities of this phase. They concluded that in deep-sea sediments and alkali saline lakes, clinoptilolite and phillipsite, without mordenite, should form at essentially ambient temperatures, and that clinoptilolite plus mordenite, without phillipsite, should form during hydrothermal alteration. As noted above, the absence of phillipsite in these rocks may be related to their age. The absence of mordenite may indicate that the temperature of alteration was too low for its formation. Alternatively, the chemical conditions may not have been favorable. Holler and Wirching (1978) determined, in experiments using basalt, phonolite, and rhyolite and a range of fluid compositions, that mordenite formation is enhanced by silica-rich, low-alkali conditions.

Honnorez (1978) reports that chabazite, analcime, and apophyllite occur in basaltic glass from Palagonia, Sicily. These minerals occur in association with saponite, gyrolite, phillipsite, gmelinite, and an opalcalcite mixture. Honnorez interprets this assemblage as being authigenic.

\section{DISCUSSION}

The secondary minerals are not uniformly distributed throughout the cored section (see Table 1). Smectite and 
Table 1. Mineralogy of veins in basalts, Hole 462A, DSDP Leg 61.

\begin{tabular}{|c|c|c|c|c|c|c|c|c|c|c|}
\hline $\begin{array}{c}\text { Sample } \\
\text { (interval in } \mathrm{cm} \text { ) }\end{array}$ & Smectite & Calcite & Quartz & Pyrite & Celadonite & $\begin{array}{c}\mathrm{Fe} \\
\text { Oxide }\end{array}$ & $\begin{array}{l}\text { Clinop- } \\
\text { tilolite }\end{array}$ & Chabozite & $\begin{array}{l}\text { Anal- } \\
\text { cime }\end{array}$ & Other \\
\hline $14-2,48-50$ & $\mathrm{x}$ & $\mathrm{x}$ & $x$ & & $\mathrm{x}$ & $\mathrm{x}$ & & & & \\
\hline $14-2,68-70$ & $\mathrm{x}$ & $\mathrm{x}$ & tr & & $\mathrm{x}$ & $\mathrm{x}$ & & & & \\
\hline $15-2,41-48 a$ & $\mathrm{x}$ & $\mathrm{x}$ & & & $\mathrm{x}$ & $\mathrm{x}$ & & & & \\
\hline $15-2,41-48 b$ & $\mathrm{x}$ & $\mathrm{x}$ & & & $\mathrm{x}$ & $\mathrm{x}$ & & & & \\
\hline $16-1,97-99$ & $\mathrm{x}$ & $\mathrm{x}$ & $\mathrm{x}$ & & $\mathrm{x}$ & & & & & \\
\hline $16-1,120-122$ & $\mathrm{x}$ & $\mathrm{x}$ & $\mathrm{x}$ & & $\mathrm{x}$ & $\mathrm{x}$ & & & & \\
\hline $17-1,17-21$ & $x$ & $\mathrm{x}$ & $\mathrm{x}$ & & $\mathrm{x}$ & $\mathrm{x}$ & & & & \\
\hline $17-1,117-119$ & $x$ & $\mathrm{x}$ & tr & & $\mathrm{x}$ & $\mathrm{x}$ & & & & \\
\hline $19-1,49-51$ & $\mathrm{x}$ & & tr & $\mathrm{x}$ & & $\mathrm{x}$ & & & & \\
\hline $19-2,7-10$ & $\mathrm{x}$ & & & $\mathrm{x}$ & & & & & & \\
\hline $27-1,51-56$ & $\mathrm{x}$ & $\mathrm{x}$ & & $\mathrm{x}$ & & & & & & \\
\hline $28-3,19-22$ & $\mathrm{x}$ & $\mathrm{x}$ & $\mathrm{x}$ & $x$ & & & & & & \\
\hline $28-3,100-103$ & $\mathrm{x}$ & & & $\mathrm{x}$ & & & & & & \\
\hline $29-5,9-12$ & $\mathrm{x}$ & $\mathrm{x}$ & $\mathrm{x}$ & & & & & & & \\
\hline $44-1,67-70$ & $\mathrm{x}$ & & & & & & $\mathrm{x}$ & & & \\
\hline $\begin{array}{l}45-1,28-30 \\
47-1,7-9\end{array}$ & $\begin{array}{l}x \\
x\end{array}$ & $\begin{array}{l}X \\
\text { tr }\end{array}$ & & & & & $\mathrm{x}$ & & & \\
\hline $48-1,125-128$ & $\hat{x}$ & tr & & & & & & & & talc (?) \\
\hline $48-4,99-101$ & $\mathrm{x}$ & $\mathrm{x}$ & & & & & & & & apophyllite \\
\hline $48-4,101-104$ & $\mathrm{x}$ & & & $\mathrm{x}$ & & & & tr & & apophyllite \\
\hline $50-3,109-112$ & $\mathrm{x}$ & & & & & & & & & \\
\hline $56-2,95-98$ & $\mathrm{x}$ & & & & & & $\mathrm{x}$ & tr & & \\
\hline $58-1,1-2$ & $\mathrm{x}$ & & & & & & $\mathrm{x}$ & & $\mathrm{x}$ & \\
\hline $58-3,123-125$ & $\mathrm{x}$ & & & & & & $\mathrm{x}$ & & & \\
\hline $61-1,21-24$ & $\mathrm{x}$ & & & & & & $\mathrm{x}$ & & & talc (?) \\
\hline $61-1,146-149$ & $\mathrm{x}$ & & & $\mathrm{x}$ & & & & & & talc (?) \\
\hline $61-2,26-29$ & $\mathrm{x}$ & tr & & $\mathrm{x}$ & & & & & & \\
\hline $62-3,119-122$ & $\mathrm{x}$ & & & & & & $\mathrm{x}$ & & & \\
\hline $63-1,15-18$ & $\mathrm{x}$ & tr & & & & & & $x$ & & \\
\hline $65-1,78-82$ & $\mathrm{x}$ & & tr & & & & & & & talc (?) \\
\hline $65-3,67-70$ & $\mathrm{x}$ & & tr & & & & & & & talc (?) \\
\hline $\begin{array}{l}70-3,64-66 \\
71-1,71-72\end{array}$ & $\begin{array}{l}x \\
x\end{array}$ & & & & & & $x$ & & & \\
\hline $73-1,28-30$ & $\begin{array}{l}X \\
x\end{array}$ & $\mathrm{x}$ & & & & & & & & \\
\hline $74-1,78-80$ & $\mathrm{x}$ & $\mathrm{x}$ & & $\mathrm{x}$ & & & & & & \\
\hline $76-1,60-62$ & $\mathrm{x}$ & $\mathrm{x}$ & & & & & & & & \\
\hline $77-1,136-138$ & $\mathrm{x}$ & $\mathrm{x}$ & & $x$ & & & & & & \\
\hline $78-1,61-63$ & $\mathrm{x}$ & $\mathrm{x}$ & $\operatorname{tr}$ & $\mathrm{x}$ & & & & & $\mathrm{x}$ & \\
\hline $79-1,111-113$ & $\mathrm{x}$ & & & & & & & & & \\
\hline $81-1,27-29$ & $\mathrm{x}$ & tr & tr & $\mathrm{x}$ & & & & & & \\
\hline $84-4,49-51$ & $\mathrm{x}$ & & & & & & & $\mathrm{x}$ & & \\
\hline $89-2,38-40$ & $x$ & $\mathrm{x}$ & & $x$ & & & & & & \\
\hline $\begin{array}{l}89-3,58-60 \\
89-3,60-66\end{array}$ & $\begin{array}{l}X \\
x\end{array}$ & & & & & & $\mathrm{x}$ & & & \\
\hline $90-1,24-26$ & & & & & & & $\mathrm{x}$ & $t r$ & & \\
\hline $90-1,141-143$ & $\mathrm{x}$ & & tr & & & & $\mathrm{x}$ & & & \\
\hline $90-2,18-20$ & $\mathrm{x}$ & & tr & tr & & & $\mathrm{x}$ & & & \\
\hline $90-2,37-39$ & $\mathrm{x}$ & & tr & tr & & & $\mathrm{x}$ & & & \\
\hline
\end{tabular}

calcite are essentially ubiquitous phases, but celadonite and $\mathrm{Fe}$ oxide occur only in Cores 14 through 17, pyrite occurs only in Core 19 and below, and the zeolites are restricted to Core 44 and below. Quartz is present throughout the hole, but usually in trace quantities below Core 44 .

These data define two distinct suites of secondary minerals: those that contain zeolites with little or no quartz (Cores 44-90) and those that contain no zeolites but abundant quartz (Cores 14-29). This division correlates exactly with the major lithologic change between thick and thin lava sheets and flows below Core 44, and microdiabase and basalt sills intruded into sediments above (Batiza et al., this volume). Further, the uppermost suite of vein minerals can be subdivided into assemblages that formed under non-oxidative conditions (Cores 19-29) and those that have undergone oxidative diagenesis (Bass, 1976).

We interpret these data as indicating at least three different episodes of vein formation and/or alteration. The first was the formation of veins in the sequence of lava sheets and flows; these veins are characterized by the assemblage consisting of smectite, clinoptilolite, calcite, pyrite, \pm chabazite, \pm analcime, \pm quartz, \pm apophyllite, \pm talc (?). This assemblage is not unequivocal in terms of its environment of formation. Scheidegger and Stakes (1977) report, however, a similar assemblage that they interpret to have formed at higher than ambient temperatures under conditions of low $\mathrm{CO}_{2}$ activity, presumably at or near a spreading center where thermal gradients were higher and a cover of calcareous sediments had not developed to a very great extent.

Our data are not inconsistent with such an interpretation. Minerals present in these veins have been found in low-grade metamorphic terrains (Seki et al., 1969; Iijima and Utada, 1972). Clinoptilolite is restricted to the lower temperatures zones in these metamorphic areas, but as previously noted, the clinoptilolite may be the product of reaction between previously existing metastable phillipsite plus silica.

Bischoff and Dickson (1975) found that anhydrite is formed when basalt reacts with sea water at $200^{\circ} \mathrm{C}$ and 500 bars; but they caution that the anhydrite may be a metastable precipitate which eventually reacts with $\mathrm{Fe}$ bearing components to form pyrite and release $\mathrm{Ca}^{2+}$, and this $\mathrm{Ca}^{2+}$ may then be taken up by zeolites. Seyfried and Bischoff (1979) conclude that anhydrite formed at 
elevated temperatures undergoes rapid retrograde dissolution with cold seawater. Thus, the absence of anhydrite in all our samples does not rule out an elevated temperature of formation.

Calcite is present in zeolite-bearing assemblages, but to a much lesser extent than in samples that contain no zeolites. This is consistent with vein formation under conditions of low $\mathrm{CO}_{2}$ activity.

The second episode of vein formation took place in the sills that occur in the upper part of the hole. The original vein assemblage consisted of smectite, calcite, quartz, and pyrite. No unequivocal temperature of formation can be determined from the available data, but Bass et al. (1974), Scott and Swanson (1976), Scheidegger and Stakes (1977), and Lawrence et al. (1979) report similar assemblages that are interpreted to have formed under conditions of low temperature and high $P_{\mathrm{CO}_{2}}$. The presence of pyrite in Leg 61 rocks indicates an environment with relatively low $P_{\mathrm{O}_{2}}$. This apparently changed after formation of the original vein material, as indicated by the presence of celadonite, Fe-oxide pseudomorphs after pyrite (Sample 462A-15-2, 41-48 $\mathrm{cm}$ (a)), and Fe-oxide (hydroxide?) stains on smectite and calcite in veins from Cores 14 through 19. Of these cores, only Core 19 contains veins that have pyrite and $\mathrm{Fe}$ oxide coexisting; pyrite is absent above Core 19, and Fe oxide is absent below Core 19. Celadonite and pyrite never occur together.

The observation of a change from an initially nonoxidative environment of vein formation to an oxidative environment is similar to observations by Scheidegger (1979) for basalts exposed along a fault scarp in the Peru-Chile trench, and is in concert with Bass's (1976) model of submarine basalt alteration. We interpret these data as indicating that the veins initially formed under relatively non-oxidizing conditions, protected from the oxygen-rich sea water by the sedimentary cover into which they intruded. This stage of vein formation is characterized by green-to-brown smectite and pyrite. After formation of the veins, oxygen-rich sea water slowly percolated through the overlying sediments and interacted with previously formed vein minerals. This resulted in oxidation in the smectites, yielding a redbrown variety, and oxidation of the pyrite, with the $\mathrm{Fe}^{3+}$ ions taken up by $\mathrm{Fe}$-oxide phases and celadonite and sulfur dissolved as sulfate. As discussed by Bass (1976), the overlying sediments act only as a diffusion barrier to sea water, not as an oxygen sink. The absence of an Fe-oxide phase in samples from below Core 19, however, indicates that oxidative diagenesis only penetrated that far. The depth of oxidation may be determined either by diffusion control of the sea water circulation by the sediments or by the uppermost igneous rocks in the sequence acting as an oxygen sink for those below. Both processes are probably important.

\section{SUMMARY}

A model for alteration processes that occurred in rocks recovered from Hole $462 \mathrm{~A}$ can be formulated from the data we have presented here and the petrologic data for the igneous rocks given by Batiza et al. (this volume). The first set of events was the outpourings of lava, forming thin and thick submarine sheet flows and pahoehoe units, represented by Core 44 and below. Sea water, circulating through fractures, reacted with the basalt before deposition of a sedimentary cover and formed veins containing zeolites, smectites, pyrite, calcite, minor quartz, talc (?), and apophyllite. This stage of alteration may be correlated with Bass's (1976) pre-burial stage, but no palagonite has been identified in these rocks, even in the glassy samples.

As spreading of the sea floor proceeded, these rocks were progressively covered with a blanket of sediment that restricted the free circulation of sea water through the fractures. This reduced circulation, together with a much lower thermal gradient, impeded alteration of these rocks, except for possible reactions of metastable phases (e.g., phillipsite and/or anhydrite).

The next major igneous episode was the intrusion of basaltic sills into the overlying sedimentary cover. Alteration of these rocks was different from alteration of the flows, because the fluid medium involved in the alteration process was the pore fluid from the sediments rather than freely circulating sea water. This pore fluid was not as oxygenated as ocean bottom water, and had higher concentrations of $\mathrm{CO}_{2}$ and $\mathrm{SiO}_{2}(\mathrm{aq})$ because of its contact with the sediments. Therefore, vein formation resulted in assemblages containing smectite, calcite, pyrite, and quartz, and is comparable to Bass's (1976) non-oxidative stage of submarine basalt alteration.

Eventually, oxygenated sea water diffused through the overlying sediments, causing oxidation of the smectite and pyrite and leading to formation of celadonite and $\mathrm{Fe}$-oxide stains and pseudomorphs after pyrite. This corresponds to Bass's (1976) oxidative diagenesis stage of alteration. The oxygenated sea water must be presently limited by diffusion to rocks recovered in Cores 19 and above, because $\mathrm{Fe}$ oxide is not present in samples from below this depth.

\section{ACKNOWLEDGMENTS}

We wish to thank Drs. T. L. Vallier and Rodey Batiza for discussions about various aspects of this research. Drs. W. E. Seyfried, Jr. and K. F. Scheidegger reviewed an earlier draft and made helpful comments.

Funds to defray the costs of sample preparation were provided by the Dean of the Graduate College of Iowa State University. One of us (P.B.) received financial support through a DHEW Mining and Minerals and Mineral Fuels Conservation Fellowship.

\section{REFERENCES}

Andrews, A. J., 1977. Low temperature fluid alteration of oceanic layer 2 basalts, DSDP Leg 37. Can. J. Earth Sci., 14:911.

Bass, M. N., 1976. Secondary minerals in oceanic basalt, with special reference to Leg 34, Deep Sea Drilling Project. In Yeats, R. S., Hart, S. R., et al., Init. Repts. DSDP, 34: Washington (U.S. Govt. Printing Office), 393-432.

Bass, M. N., Moberly, R., Rhodes, J. M., et al., 1974. Volcanic rocks cored in the central Pacific, Leg 17, Deep Sea Drilling Project. In Winterer, E. L., Ewing, J. I., et al., Init. Repts. DSDP, 17: Washington (U.S. Govt. Printing Office), 429-504

Berger, W. H., and von Rad, U., 1972. Cretaceous and Cenozoic sediments from the Atlantic Ocean. In Hayes, D. E., Pimm, A. C., et al., Init. Repts. DSDP, 14: Washington (U.S. Govt. Printing Office), 787-954.

Bischoff, J. L., and Dickson, F. W., 1975. Seawater-basalt interaction at $200^{\circ} \mathrm{C}$ and 500 bars: Implications for origin of sea-floor 
heavy-metal deposits and regulation of seawater chemistry. Earth Planet. Sci. Lett., 25: 385.

Boles, J. R., 1977. Zeolites in low-grade metamorphic grades. In Mumpton, F. A. (Ed.), Mineralogy and Geology of Natural Zeolites: Short Course Notes-Mineral. Soc. Am. (Vol. 4): Blacksburg, Virginia (Mineral. Soc. Am.), 103.

Boles, J. R., and Wise, W. S., 1978. Nature and origin of deep-sea clinoptilolite. In Sand, L. B., and Mumpton, F. A. (Eds.), Natural Zeolites: Occurrence, Properties, Use: Zeolite '76 Conference (Tucson): London (Pergamon), p. 235.

Hawkins, D. B., Sheppard, R. A., and Gude, A. J., 3rd, 1978. Hydrothermal synthesis of clinoptilolite and comments on the assemblage phillipsite-clinoptilolite-mordenite. In Sand, L. B., and Mumpton, F. A. (Eds.), Natural Zeolites: Occurrence, Properties, Use: Zeolite '76 Conference (Tucson): London (Pergamon), p. 337.

Hay, R. L., 1977. Geology of zeolites in sedimentary rocks. In Mumpton, F. A. (Ed.), Mineralogy and Geology of Natural Zeolites: Short Course Notes-Mineral. Soc. Am. (Vol. 4): Blacksburg, Virginia (Mineral. Soc. Am.), 53.

Hay, R. L., 1978. Geologic occurrences of zeolites. In Sand, L. B, and Mumpton, F. A. (Eds.), Natural Zeolites: Occurrence, Properties, Use: Zeolite '76 Conference (Tucson): London (Pergamon), p. 135.

Holler, H., and Wirsching, U., 1978. Experiments on the formation of zeolites by hydrothermal alteration of volcanic glasses. In Sand, L. B., and Mumpton, F. A. (Eds.), Natural Zeolites: Occurrences, Properties, Use: Zeolite '76 Conference (Tucson): London (Pergamon), p. 329.

Honnorez, J., 1978. Generation of phillipsites by palagonitization of basaltic glass in sea water and the origin of K-rich deep-sea sediments. In Sand, L. B., and Mumpton, F. A. (Eds.), Natural Zeolites: Occurrence, Properties, Use: Zeolite '76 Conference (Tucson): London (Pergamon), p. 245.

Iijima, A., 1978. Geological occurrence of zeolite in marine environments. In Sand, L. B., and Mumpton, F. A. (Eds.), Natural Zeolites: Occurrence, Properties, Use: Zeolite '76 Conference (Tucson): London (Pergamon), p. 175.

Kastner, M., 1976. Diagenesis of basal sediments and basalts at Sites 322 and 323, Leg 35, Ballingshausen Abyssal Plain. In Hollister, C. D., Craddock, C., et al., Init. Repts. DSDP, 35: Washington (U.S. Govt. Printing Office), 513-528

Kastner, M., and Stonecipher, S. A., 1978. Zeolites in pelagic sediments of the Atlantic, Pacific, and Indian oceans. In Sand, L. B., and Mumpton, F. A. (Eds.), Natural Zeolites: Occurrence,
Properties, Use: Zeolite '76 Conference (Tucson): London (Pergamon), p. 199.

Kempe, D. R. C., 1974. The petrology of the basalts, Leg 26. In Davies, T. A., Luyendyk, B. P., et al., Init. Repts. DSDP, 26: Washington (U.S. Govt. Printing Office), 465-504

Kempe, D. R. C., 1976. Petrological studies on DSDP Leg 34 basalts: Nazca Plate, eastern Pacific Ocean. In Yeats, R. S., Hart, S. R., et al., Init. Repts. DSDP, 34: Washington (U.S. Govt. Printing Office), 189-214.

Lawrence, J. R., Drever, J. I., Anderson, T. F., et al., 1979. Importance of alteration of volcanic material in the sediments of Deep Sea Drilling Site 323: Chemistry, ${ }^{18} \mathrm{O} /{ }^{16} \mathrm{O}$ and ${ }^{87} \mathrm{Sr} /{ }^{86} \mathrm{Sr}$. Geochim. Cosmochim. Acta, 43:573.

Scarfe, C. M., and Smith, D. G. W., 1977. Secondary minerals in some basaltic rocks from DSDP Leg 37. Can. J. Earth Sci., 14:903.

Scheidegger, K. F., 1979. An oxidative diagenetic overprint on hydrothermally altered tholeiitic basalts: Chemical and mineral consequences. Geol. Soc. Am. Abstracts with Programs, 11:511. (Abstract)

Scheidegger, K. F., and Stakes, D. S., 1977. Mineralogy, chemistry and crystallization sequence of clay minerals in altered tholeitic basalts from the Peru Trench. Earth Planet. Sci. Lett., 36:413.

Scott, R. B., and Swanson, S. B., 1976. Mineralogy and chemistry of hydrothermal veins and basaltic host rocks at Hole 319A and Site 321. In Yeats, R. S., Hart, S. R., et al., Init. Repts. DSDP, 34: Washington (U.S. Govt. Printing Office), 377-380.

Seki, Y., Oki, Y., Matsuda, T., et al., 1969. Metamorphism in the Tansawa Mountains, central Japan. J. Japan. Assoc. Mineral. Petrol. Econ. Geol., 61:1.

Seyfried, W. E., Jr., and Bischoff, J. L., 1979. Low temperature basalt alteration by seawater: An experimental study at $70^{\circ} \mathrm{C}$ and $150^{\circ} \mathrm{C}$. Geochim. Cosmochim. Acta, 43:1937.

Seyfried, W. E., Shanks, W. C., and Bischoff, J. L., 1976. Alteration and vein formation in Site 321 basalts. In Yeats, R. S., Hart, S. R., et al., Init. Repts. DSDP, 34: Washington (U.S. Govt. Printing Office), 385-392.

Seyfried, W. E., Shanks, W. C., and Dibble, W. E., Jr., 1978. Clay mineral formation in DSDP Leg 34 basalt. Earth Planet. Sci. Lett., 41:265.

Stonecipher, S. A., 1978. Chemistry of deep-sea phillipsite, clinoptilolite, and host sediments. In Sand, L. B., and Mumpton, F. A., (Eds.), Natural Zeolites: Occurrences, Properties, Use: Zeolite '76 Conference (Tucson): London (Pergamon), p. 221. 